\title{
The influence of infection on society
}

\author{
Peter Lachmann
}

The main theme of this chapter is the enduring and extensive influence that combating infection has had on human life and society. This is a topic much neglected in accounts of human history. Moreover, the influence of infection is not restricted to humans but can be seen throughout the living world from bacteria and fungi to plants and animals.

The bacteriophages that infect bacteria have been invaluable tools to study molecular biology though their promise as antibacterial agents in medicine has not so far been fulfilled. The devastating effect of infection on the tree population in this country has been demonstrated by Dutch elm disease, and more recently by ash dieback, which have had a large effect on the overall tree population.

In animals, there is a very interesting review by Hamilton et al. (1990) who analysed why it was that primitive animals always adopt sexual reproduction as opposed to vegetative reproduction as used in many plants. They came to the conclusion that the advantage of sexual reproduction is that it provides a mechanism to reassort the genes that are concerned with resistance to infection at each generation. In other words, the reason we have sex is to combat infection. Here, however, I will restrict myself to discussing infectious disease and its effects on human societies.

It is likely that humans became significantly more susceptible to infectious disease as a result of the agricultural revolution about 10,000 years ago. This is less than 10 per cent of the period in which modern humans, Homo sapiens, have existed. For the first 90 per cent of human existence the communities were small, they tended to move about and not occupy the same site for long, and they had no domestic animals. Although evidence on the incidence of infection before the agricultural revolution is sparse, it is highly plausible that it was less. The coming of larger communities living at fixed sites led to their contaminating their water supplies with their own faeces and promoted orofaecal spread of infection. The fact that they lived in larger communities will itself have helped to spread infections by the respiratory route but perhaps the most important feature was the 
Table 1.1 Examples of human infectious diseases of animal origin

\begin{tabular}{|c|c|c|c|c|}
\hline Disease & Microbe & Animal source & $\begin{array}{l}\text { Date of } \\
\text { crossover }\end{array}$ & Location \\
\hline malaria & parasite & chimpanzee & c. 8000 bce & \\
\hline smallpox & virus & ruminant? & $>2000$ bce & \\
\hline tuberculosis & mycobacterium & ruminant? & $>1000$ bce & \\
\hline \multirow{2}{*}{ typhus } & rickettsia & rodent & 430 bce & Athens \\
\hline & & & 1492 ce & Spain \\
\hline \multirow[t]{3}{*}{ plague } & bacterium & rodent & 541 ce & Justinian Plague \\
\hline & & & 1347 ce & Black Death \\
\hline & & & 1665 ce & $\begin{array}{l}\text { Great Plague of } \\
\text { London }\end{array}$ \\
\hline dengue & virus & monkey & c. 1000 ce & \\
\hline yellow fever & virus & monkey & 1641 се & \\
\hline Spanish flu & virus & bird, pig & 1918 ce & worldwide \\
\hline AIDS/HIV-1 & virus & chimpanzee & c.1931 ce & \\
\hline AIDS/HIV-2 & virus & monkey & 20th century & \\
\hline
\end{tabular}

Modified from Weiss (2001: 960)

domestication of animals. It is quite remarkable how many of the common infectious diseases appear to have a zoonotic origin (Weiss 2001). Table 1.1 shows some examples.

The close association of humans with the animals that they kept for hunting or as pets or as sources of meat and milk or hides or wool is likely to have caused a huge increase in the burden of infectious disease. This led to a human mortality pattern shown in Figure 1.1 where more than half of those born were dead before the age of 5 and thereafter mortality was more or less continuous, so that 50 per cent of the remaining population were dead before the age of 40. It is nevertheless interesting that the modal age of adult death, i.e. the age at which the largest number of people died in old age has probably been around 70 since biblical times at least - so that it is not that humans were at that time less capable of surviving for their three score years and ten, but that infectious disease often prevented them from doing so.

\section{Infection, mortality and religion}

Humans are probably unique in being aware of their mortality from early life. This awareness of mortality combined with the mortality pattern shown in Figure 1.1 will certainly have contributed to views on life and its significance and to have promoted the idea of life after death, or of repeated reincarnation, as a way of coping with the loss of so many young children and the constant threat of death throughout life. This can be seen as 


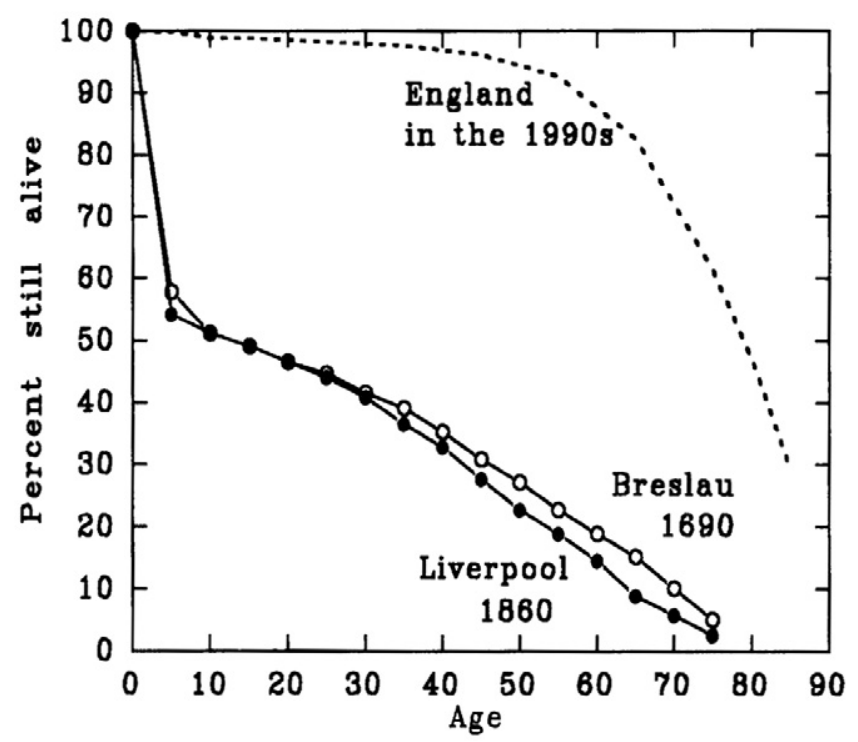

Figure 1.1 A history of mortality. Pattern of survival in seventeenthcentury Breslau (which may have been typical for the times), nineteenthcentury Liverpool (which had the lowest survival for any city in nineteenth-century England) and England in the 1990s (Cairns 1997)

contributing greatly to the growth of religions which place an emphasis on some continued existence after death, or on repeated incarnation.

It is, however, remarkable that there is one religion, the original teachings of Buddha, which regards repeated reincarnation not as an achievement to be desired but one from which one eventually wishes to escape. This escape is to nirvana, the state of absolute oblivion. This is achieved through enlightenment which requires freeing oneself of all desires. Buddha considered belief in $\operatorname{god}(\mathrm{s})$ as a desire, so that early Buddhism was anti-theistic. Buddha insisted that he was not a god. That humans achieve total oblivion after death is integral to modern secular beliefs except that it is no longer thought to be a necessity either to achieve enlightenment or to go through many cycles of reincarnation before oblivion can be achieved.

\section{Making things better}

However, the secularisation of society that accompanied the European Enlightenment really became widely established only after mortality patterns began to improve. This was brought about largely by three great contributions to fighting infectious disease.

The first improvement was better hygiene and public health, particularly the provision of clean water supplies and effective sewage disposal; but also 
more hygienic ways of preparing and storing food. An important early example showing the importance of clean water was the work of John Snow who in 1854 traced a large epidemic of cholera to the use of water from a pump in Broad Street in London. He persuaded the local authority to remove the pump handle and the epidemic promptly came to an end. It still took a long time thereafter before systematic provision of clean water (and chlorination where necessary) became enforced even in England. The 'great stink' in central London in 1858, by afflicting the Houses of Parliament, led to the provision of an effective sewage disposal system being devised by Joseph Bazalgette and built between 1859 and 1875. This again had a major beneficial effect on the incidence of cholera in London. More recently, the introduction of domestic refrigerators in the early twentieth century and of domestic freezers in the 1940s made a large contribution to reducing food-borne infection - as well as greatly reducing stomach cancer by reducing the use of wood smoke (with its carcinogens) to preserve food.

The second improvement was the introduction of vaccination. This first reached the West in the form of variolation against smallpox in the eighteenth century. Vaccination against smallpox using cowpox was introduced at the very end of that century. Both of these were quite empirical procedures, and are described in more detail in the account of smallpox below. The first involved administering a tiny amount of pus from a smallpox lesion which gave rise to a (usually) mild and localised attack of the disease. The second used lymph from a cow suffering with cowpox, a related virus, it having been observed that milkmaids who had caught cowpox while milking cows did not thereafter catch smallpox.

Vaccination based on an appreciation that infectious disease was due to microorganisms does not really start until the nineteenth century and the seminal work of Pasteur and of Koch and their associates and the rise of immunology. Their effects are not really seen to any great extent until the beginning of the twentieth century and particularly since mass vaccination against many diseases has been introduced on an increasingly worldwide basis (Table 1.2).

The discovery of antibiotics was originally made by René Dubos in 1938 who recognised that bacteria survive in soil by secreting substances that inhibit the growth of other bacteria. His original antibiotics, gramicidin and tyrocidin are still used topically but are too toxic for systemic use. Probably for this reason, he was, unjustly in my view, not given a Nobel prize. It was after the isolation by Florey and Chain in 1941 of penicillin, an antibiotic made by a fungus which is not toxic in mammals, that antibiotic discovery developed into a mega-industry. This was the third major factor in reducing the mortality from infectious disease in the period after the Second World War. No new antibiotics using the Dubos model have been discovered for some years now and the growth of antibiotic resistance among bacteria is giving rise to major concerns that bacterial infection may once more become a serious problem for the human population. The 
Table 1.2 The effectiveness of vaccines

\begin{tabular}{lcccc}
\hline & $\begin{array}{c}\text { Max. cases } \\
\text { pre-vaccine }\end{array}$ & $\begin{array}{l}\text { Year of } \\
\text { max. cases }\end{array}$ & $\begin{array}{c}\text { Cases in } \\
1995\end{array}$ & \% change \\
\hline pertussis & 265,269 & 1934 & 4315 & -98.37 \\
measles & 894,134 & 1941 & 309 & -99.97 \\
mumps & 152,209 & 1968 & 840 & -99.45 \\
congenital rubella & $20,000+$ & $1964 / 65$ & 7 & -99.96 \\
$\quad$ syndr. & 21,269 & 1952 & 0 & -99.99 \\
polio & 0 & & $10,594^{*}$ & \\
adverse events & & & & \\
\hline
\end{tabular}

* For all these vaccines plus H.Influenzae, diphtheria and tetanus (data for USA from CDC)

development of chemotherapy for viral infections is a field that is still expanding. While effective drugs now exist against some important viruses, HIV being a good example, there are many viruses, measles for example, for which no effective chemotherapy yet exists; and others like flu where the treatments are not particularly effective.

\section{Older practices that fight infections}

However, even in a much more distant past, one can see in the prescriptions of various religions, practices that will have led to increased resistance to infectious disease. This was certainly not the reason why such practices were introduced - at a time when the causes of communicable diseases were unknown. Examples here include the prohibition of cannibalism. There are probably multiple reasons why particular religions forbade cannibalism while others did not, but it became the case that communities which rejected cannibalism survived better. This was, at least in part, due to the spread of spongiform encephalopathies, diseases that in humans include kuru and Creutzfeldt-Jakob disease, which can be spread by eating human brain. It is therefore fairly clear that cannibalistic societies were at increased danger of succumbing to the spread of these lethal diseases. The Fore Tribe in New Guinea very nearly died out from kuru in the early twentieth century before the Australian government who then ruled New Guinea forbade the practice of ritual cannibalism.

It is likely that male circumcision persisted in some communities for an analogous reason. There is little doubt that the spread of various sexually spread diseases, not just HIV, is reduced by circumcision and it is likely that this practice helped to reduce the incidence of potentially lethal diseases like syphilis and hepatitis B infection, and prevented women becoming infertile as a result of non-lethal diseases such as gonorrhoea. These consequences again were clearly not the reason for the introduction of 
circumcision but the improved survival of communities practising it will have favoured its survival.

\section{Historical pandemics and their effects on society}

It is quite difficult to imagine now the scale of mortality that was produced by major pandemics of infectious disease. There must be many great pandemics of which we have no record but there are several which certainly had a major influence on the course of human history.

The Athenian plague between 430 and 426 вс during the Peloponnesian War, probably contributed greatly to the demise of the Athenian empire. The organism causing this plague is not certainly known. Typhus, smallpox, measles and flu have all been suggested. So has typhoid but that is implausible. It is estimated that 25 per cent of the city's population died $(75,000-100,000$ people) (Littman 2009).

The Antonine plague, between AD 165 and 168, is likely to have accelerated the fall of the Western Roman Empire. This is believed to have been a smallpox epidemic and to have killed 3.5-5 million people (Wikipedia 2017a).

Plague is due to a bacterium, Yersinia pestis commonly known as the plague bacillus, and typically gives rise to 'bubonic plague' which is spread by fleas from rats to humans. During pandemics it can also spread directly from human to human - giving rise to the even more deadly 'pneumonic plague'. Plague has been one of the greatest scourges to afflict humans.

The Justinian plague (Wikipedia 2017b), which decimated the population of both the Byzantine Empire and the Persian Empire in the sixth to seventh centuries from 542 to about 750, may have killed 100 million people worldwide. It is argued by Holland in his book In the Shadow of the Sword (2013) to have made the Arab conquests possible. The Arabs, in his view, lived in dispersed settlements much further south, somewhere near Yemen, where rats were much less frequent and so had not been exposed to decades of the Justinian plague. This allowed them with relative ease to conquer both large parts of the Byzantine Empire and of the Persian Empire. Holland suggests that Islam originated as a need to control these great new acquisitions and followed the Arab conquest rather than preceding it. He also believes that the original Mecca was far further south than Mecca is now and in consequence out of the range of the plague.

The Black Death was also due to Yersinia pestis. The Black Death in the early fifteenth century was a catastrophe on a scale that is now quite difficult to imagine. It is estimated that more than one-third of the population of much of Europe died over a relatively short period and in some communities in East Anglia it has recently been shown that the production of ceramics fell by 70 to 80 per cent reflecting the enormous loss of population. It is certainly regarded as having caused the end of serfdom since there was such a shortage of labour that labourers were no longer bound to stay at their original sites of serfdom but could sell their labour 
throughout the country. This so-called 'second wave' of plague continued for centuries in Europe with intermittent outbreaks culminating in Britain in the great London Plague in 1665. This also caused a very substantial death rate.

It has been speculated that the decline of plague after this time was the result of the gradual replacement of the indigenous black rat by the larger brown Norway rat which appears to be a less congenial host for the rat flea. Rather later, the population became less tolerant of carrying fleas too!

Plague, however, still persists. In parts of the United States it is endemic and there was a small outbreak in North Africa during the Second World War which, greatly exaggerated, forms the subject of Camus's novel La Peste (Camus 1947). However, Yersinia pestis is sensitive to antibiotics and this has caused plague largely to die out, although the emergence of antibioticresistant plague bacteria is now giving rise to concern.

Most other major plagues that we know of have been caused by viruses rather than bacteria. The most devastating of these in human history has been smallpox. However, it is so far the only human pandemic disease to have been eradicated from the planet (Glynn and Glynn 2004; Rhodes 2013). Smallpox has been a scourge among humans since ancient times. It is probably of zoonotic origin and related pox viruses occur in many mammalian species. It is known to have been in the Far East centuries ago and it is there that the first attempts at prevention were established by variolation. This was introduced from the East to Turkey where it was used particularly to immunise the Circassian women who were used as slaves by the Turks and whose freedom from smallpox scars was held to be of greater importance than the occasional death. From Turkey, variolation was introduced into England through the good offices, in part, of Lady Mary Wortley Montagu (as shown in her letter below) and became reasonably widespread.

\section{Extract of a letter from Lady Mary Wortley Montagu in Constantinople to Mrs Sarah Chiswell, written in I7I7 (Lynch n.d.: Letter XXXI)}

The small-pox, so fatal, and so general amongst us, is here entirely harmless by the invention of ingrafting, which is the term they give it . . .

Every year thousands undergo this operation; and the French ambassador says pleasantly, that they take the small-pox here by way of a diversion, as they take the waters in other countries. There is no example of any one that has died in it; and you may believe I am very well satisfied on the safety of this experiment, since I intend to try it on my dear little son ...

I am patriot enough to take pains to bring this useful invention into fashion in England; and I should not fail to write to some of our doctors very particularly about it, if I know any one of them that I thought had virtue enough to destroy such a considerable branch of their revenue for the good of mankind.

Variolation was never entirely safe and people who were variolated had to be isolated for some period to avoid infecting others. However, it was this practice that enabled Edward Jenner to do a trial of vaccination with 
cowpox in one patient. This was given to a boy, James Phipps, who was subsequently variolated and the variolation was shown not to take. This led to the widespread introduction of vaccination with cowpox and subsequently with vaccinia (whose exact animal origins are unknown) to prevent smallpox - the first great triumph of vaccination at the end of the eighteenth century.

Although smallpox epidemics occurred throughout the Old World, it was unknown in the New World and it was smallpox (together with measles) that enabled small numbers of Spanish conquistadores to conquer Mexico and Peru. Although other explanations, like more ruthless warfare, better guns, or horses have been quoted, it is almost certainly the case that they brought smallpox with them that caused their rapid success (Oldstone 2010). It is recorded that Cortez had a slave in his entourage who was incubating smallpox when they arrived in America. In populations with no herd immunity to smallpox, the mortality was extremely great. Similar findings were recorded in California where the establishment of mission stations was always followed by the death of much of the local population, the only survivors being the offspring of the native women and the soldiers guarding the missions (and probably the priests too). It is strange that the cause of this mortality was never really considered at the time.

Disgracefully, smallpox was also used in biological warfare, even by the British. Pox viruses are extremely stable in the environment and blankets that had been exposed to a smallpox patient were given to native Americans during the siege of Fort Pitt in 1763 to infect the natives - an entirely shameful episode and quite probably not unique.

The eradication of smallpox by a massive vaccination programme in the 1960 s is one of the great triumphs of preventive medicine. It would be very difficult to achieve now because of the increased emphasis on individual consent. The smallpox eradication campaign was done with what is called 'community consent' so that the local authority would agree and then all the available children would be lined up and vaccinated. Attempts to eradicate measles and polio, two other great scourges of humankind, are still not fully complete although they are very slowly reaching completion.

Eradication by vaccination is, of course, possible only where humans are the only host for the organism and cannot be achieved if there are alternative hosts such as in the case of yellow fever and many other diseases.

Another major epidemic, of which there are a few human survivors who still remember it, was the flu epidemic that followed the First World War in 1918. It is reckoned that this killed some forty million people - more than were killed in the war. Flu is a constant companion of humans and has given rise to frequent epidemics as well as the regular presence of flu in the population, but it is only occasionally that disastrous pandemics such as those of 1918-19 arise. Flu virus has an unusual genome where there are eight separate stretches of genome in the virus, which can therefore reassort rather than recombining and this gives the virus a great capacity 
of rapidly induced changes in its antigenic structure. There has more recently been a major outbreak of bird flu, which is contagious and can be lethal to humans, but which fortunately so far has not shown the ability to spread readily from one human to another. This again, however, cannot be guaranteed to continue indefinitely although the major haemagglutinin antigen of the bird flu virus (H5) is not known ever to have caused pandemics in man.

Another current global viral pandemic is HIV. There are two HIV viruses - HIV1 and HIV2. Both are lentiviruses but they are distinct. HIV1 is endemic in chimpanzees in Central Africa and HIV2 in sooty mangabeys in West Africa. The spread of these viruses to humans probably occurred some decades ago but they became a major problem much more recently, from the 1970s. It is highly likely (but difficult to fully establish) that the cause of this accelerated spread was the introduction into Africa of hypodermic syringes and needles for vaccination and other medical purposes. At that time the danger posed by their misuse after their original use was not recognised and no efficient disposal procedure was put in place. The syringes and needles allowed materials from animals, monkeys in particular, to be injected as part of native African medicine rather than just smeared as was previously the custom. This is likely to have caused the catastrophic explosion in the amount of HIV present and facilitated sexual spread - both homosexual and heterosexual and allowed spread to the USA, Europe and the rest of the world. Although relatively effective antiviral drugs against HIV have been developed, there is still no effective vaccine against the virus, which is highly immunosuppressive and whose cellular host is the T-lymphocyte, the major mediator of antiviral immunity. If this account of the pandemic spread of HIV is correct, it is a particularly tragic example of how interventions made with the best possible intentions can have catastrophic side effects.

Other infectious diseases have exercised a major effect on human society not in the form of pandemics but because they are continuously present in various human populations and have been major causes of mortality: among the most important of these is tuberculosis caused by Mycobacterium tuberculosis. Mycobacteria are intracellular bacterial infections which are difficult to neutralise and are contained by cellular immunity which is however also responsible for much of the pathology produced by the infection. Tuberculosis has been a major cause of death for centuries and, as is known from nineteenth-century literature, was regarded at that time with the same apprehension as cancer is at the present time. There is an excellent account of tuberculosis given by René Dubos (1987), which concerns attempts to control it. Some degree of immunity can be produced by infection with attenuated organisms, the so-called Bacillus Calmette-Guérin (BCG), but this is more effective in northern than in southern climates, though it does largely prevent everywhere the more lethal forms of childhood tuberculosis - miliary tuberculosis and tuberculous meningitis - and for this reason it 
is well worth persevering with. However, effective control of tuberculosis was only achieved when antituberculous chemotherapy was produced notably streptomycin - followed by isoniacid and polyaminosalicylic acid. The growth of multi-drug-resistant tuberculosis at the present time presents a very serious hazard to public health globally in the next decades.

In and around the tropics, malaria is a major endemic scourge. It is caused by a protozoan parasite - Plasmodium - of which there are several species, Plasmodium falciparum being the most important in man. It is spread by the bite of the anopheles mosquito. Malaria is an important cause of chronic disease in adults and of death in children. Although there are effective treatments, it is still a major cause of death and morbidity in lower-income countries around the tropics.

\section{Effects of infection on human genetic variation}

Malaria is the canonical example of a rather different way in which infection has impacted human society - by its selective effect on human genetic polymorphisms. Plasmodia infect red blood cells and their ability to do so efficiently is influenced by the haemoglobin the cells carry. There is a haemoglobin variant - sickle cell haemoglobin - which when there is a single copy of this gene gives some slight protection in young children against malaria. This gene has been selected for in areas were malaria was common. Where subjects are homozygous for the sickle gene they suffer from sickle cell anaemia - an unpleasant disease which requires repeated blood transfusion throughout life. This, and a variety of analogous haemoglobin variants, have become a real problem for countries like Sardinia and Cyprus where malaria has been eradicated and where treating these haemoglobinopathies takes up a considerable fraction of their health budget.

Attempts have been made to eliminate these haemoglobin alleles. The Roman Catholic Church has given its approval to the testing of people before marriage and forbidding the marriage of two carriers of the disease, i.e. two heterozygotes. This is not a great idea. It is difficult to enforce and therefore doesn't work well and in addition it is a solution that is 'dysgenic', i.e. it leads to the increase in the number of the harmful genes rather than a decrease. If heterozygotes are not allowed to marry each other, there will be no breed-out of the homozygotes who carry two copies of the gene and an increasing percentage of the population will become heterozygous. The 'eugenic' solution would be to let people breed at will but where two heterozygotes breed together, the foetus should be checked for the presence of the gene and aborted if homozygous. With modern medical technology, this no longer requires invasive biopsy of the early foetus because genetic analysis can be done on foetal cells that pass into the maternal circulation. By this non-invasive technique the homozygotes can be identified early in pregnancy and aborted at an early stage. This still gives problems to those religions, largely Roman Catholics, who believe that the embryo acquires full human 
status at the moment of conception. This, however, is a modern idea, propounded first by Pope Pius IX in 1869, and has no origins in more ancient teachings. It was probably an attempt to bring the teachings of the Church in line with what was then known of human embryology. In this respect it was entirely misplaced. Pius IX and his contemporaries did not realise that the majority of fertilised eggs to which they ascribe full moral status do not even implant in the uterus; and, since they have had no opportunity to sin, they would form the majority population of heaven (or limbo) - a concept that I think would be foreign to the thinking of even the most right-wing Catholics.

There has been much written on the moral status of the embryo, that by the late Gordon Dunstan (1984) being a good example. I think it is widely accepted, among philosophers at least, that full human status cannot be granted unless there is some form of sentience and intentionality. There is no possibility of sentience when an embryo has no central nervous system and no sense receptors. If it can neither hear, nor feel, nor smell, or see, then it is not capable of being sentient and is not appropriately regarded as having achieved full or even appreciable moral status.

It is clear that the removal of these haemoglobin variants that once were important in resisting malaria need to be eliminated if the health services in many of these countries are to survive, and this is an area where it really is important that some rationality is applied.

The human genetic locus that shows the most variability is known as the major histocompatibility complex (MHC). These antigens are responsible for binding peptides derived from pathogens and allowing T-lymphocytes to react with them, and because there are so many antigenic variants it is important that there is a great assortment of these antigens. This is the group of antigens in mammals that correspond to the ones that Hamilton was referring to when he said that we had sex because of infection and they remain a vital component of our resistance. They are one of many reasons why excessive inbreeding in human communities can cause their demise because there are insufficient variants, and one particular infection can wipe out a whole population. This is another example of where a religious prohibition has survival value that is unlikely to bear any relation to the reasons for which it was introduced.

\section{Conclusion}

The consequence of improved hygiene and vaccination, antimicrobial and antiviral therapy has led to great changes in the mortality curves (see Figure 1.1) so that now it is relatively unusual for humans, in the developed world, to die of natural causes before the age of 60 and mortality has become concentrated in old age. As already said, this has led to a very great change in attitude to mortality and is perhaps more important in the secularisation of the world than is commonly realised. This has also led to a huge population 
explosion, particularly because of the reduction in childhood mortality, which is relatively easy to achieve and where the adoption of effective contraception has failed to balance the reduced mortality. Most religious prescription, particularly in regard to reproductive practices, is still that of an endangered species with enormous emphasis being placed on the duty, as well as the right, to reproduce. With the changes in society that place more emphasis on personal autonomy, even those restrictions which previously applied to procreation outside marriage have been abandoned and this effect may have even been exaggerated.

It is entirely self-evident that unless effective steps are taken to stop the growth of the human population, then there is a serious threat to the survival of mankind even in the medium term. No amount of reduction in $\mathrm{CO}_{2}$ output, although highly desirable to protect against global warming, or in the consumption of other products needed for human life, will prevent catastrophe without the control of human population. There is sadly, in many parts of the world, still no serious attempt to see this done.

On the other hand, reduction in human population may be brought about by other means. The rejection of vaccination on irrational grounds, the abuse of antibiotics, the increase in global travel and threat of biological warfare, are all dangers to the future of the human race from infectious disease, as is the possibility, looking more serious now than at any time since the 1960s, of nuclear war. It may be that the second half of the twentieth century will come to be seen as a golden period, certainly with regard to infectious disease. The possibility that we will be unable to control drug-resistant infections such as tuberculosis, or of other bacteria, is not at all unreal, though it is possible that science and human ingenuity may still win through.

What is totally clear is that the changes in human behaviour necessary to prevent disaster will need the participation of those who understand the roots and ethics of human behaviour as well as the underlying science.

\section{References}

Cairns, J. (1997), Matters of Life and Death: Perspectives on Public Health, Molecular Biology, Cancer, and the Prospects for the Human Race, Princeton, NJ: Princeton University Press.

Camus, A. (1947), La Peste, Paris: Gallimard.

Dubos, R. (1987), The White Plague: Tuberculosis, Man, and Society, New Brunswick, NJ: Rutgers University Press.

Dunstan, G. R. (1984), 'The moral status of the human embryo: a tradition recalled', Journal of Medical Ethics, 10.1: 38-44.

Glynn, I., and Glynn, J. (2004), The Life and Death of Smallpox, London: Profile Books.

Hamilton, W. D., Axelrod, R., and Tanese, R. (1990), 'Sexual reproduction as an adaptation to resist parasites (a review)', Proceedings of the National Academy of Sciences of the United States of America, 87.9: 3566-73 
Holland, T. (2013), In the Shadow of the Sword, London: Little, Brown.

Littman, R. J. (2009), 'The plague of Athens: epidemiology and paleopathology', Mount Sinai Journal of Medicine, 76.5: 456-67.

Lynch, J. (ed.) (n.d.) Letters of the Right Honourable Lady Mary Wortley Montagu; Written during Her Travels in Europe, Asia, and Africa, to Persons of Distinction, Men of Letters, etc. in Different Parts of Europe (London, 1790), https:// andromeda.rutgers.edu/ jlynch/Texts/montagu-letters.html (last accessed 26 October 2017).

Oldstone, M. B. A. (2010), Viruses, Plagues and History: Past, Present and Future, Oxford, Oxford University Press.

Rhodes, J. (2013), The End of Plagues: The Global Battle Against Infectious Disease, New York: Palgrave Macmillan.

Weiss, R. A. (2001), 'The Leeuwenhoek Lecture 2001. Animal origins of human infectious disease', Philosophical Transactions of the Royal Society of London. Series B: Biological Sciences, 356.1410: 957-77.

Wikipedia (2017a), 'Antonine Plague', https://en.wikipedia.org/wiki/Antonine_Plague (last accessed 26 October 2017).

Wikipedia (2017b), 'Plague of Justinian', https://en.wikipedia.org/wiki/Plague_of_ Justinian (last accessed 26 October 2017). 